\title{
Effect of Antistress agents on Haemato-Biochemical profiles of broiler and breeder hen druing summer
}

\author{
Saikat Roy $*$ and S. C. Mishra \\ Post Graduate Department of Poultry Science \\ Faculty of Veterinary Science and Animal Husbandry \\ Orissa University of Agriculture and Technology, Bhubaneswar-751003 \\ * Corresponding author e-mail: saikatroyard@yahoo.co.in
}

\begin{abstract}
An experiment was carried out to evaluate the effect of five commonly used antistress agents on haemato-biochemical profiles of broiler and broiler breeder hen. In case of broiler, significant differences were observed between treatment groups for haemoglobin concentration, total RBC and total WBC count, total blood glucose, total serum protein, total serum albumin, total alkaline phosphatase activity and total serum cholesterol level. No definite trend was observed amongst the treatment groups and control for total blood glucose content and total alkaline phosphatase activity. It is apparent that the groups fed with antistress agents like Stress roak and Venlyte had lowest serum cholesterol level compared to other groups. In case of broiler breeder hen difference between treatment groups were significant for haemoglobin content, but not for total RBC and WBC count. Differences between treatment groups although were not significant statistically for total serum protein, however differences between treatment groups were highly significant for total blood glucose.
\end{abstract}

Key Words: Antistress agents, Haemato-biochemical profiles, Broiler, Broiler breeder hen.

\section{Introduction}

High ambient temperature and humidity are considered as the major stressors to which poultry are exposed in coastal belt of Orissa during summer. Elevated heat and humidity are much more stressful to the birds than high temperature alone. This heat stress effect is more pronounced in fast growing commercial broilers and non selected meat type lines. Considering the above situation, different antistress agents are being administered in the diet of broiler and broiler breeder hen to overcome heat stress. This article reports the effect of five commonly used antistress agents on haemato-biochemical profiles of broiler and broiler breeder hen

\section{Material and Methods}

An experiment was conducted on 216 broiler breeder hens and 540 day old broiler chicks of dam line maintained at experimental poultry farm, Orissa Veterinary College, O.U.A.T., Bhubaneswar. Five antistress agents were tested. These were Vitamin- C (ascorbic acid), Sodium bi carbonate, Zeetress ( M/S Indian Herbs, Saharanpur, U.P.), Stress roak ( M/S Dabur India Pvt. Ltd., New Delhi) and Venlyte (M/S Venky Pharmaceutical of Venkateswar Group of Company, Pune ).
540 day old unsexed chicks of broiler dam line were randomly divided into six groups of 90 chicks. Each 90 chicks forming each experimental group for testing of five antistress agents and one group to be used as control. Each group was further sub- divided into three sub groups of 30 chicks each to serve as replicate, thus six treatment groups each having three replicates.

In addition to this, 216 broiler breeder hens were divided into six groups of 42 birds ( 36 female and 6 male). The average age of the birds was about 56 weeks at the beginning of the experiment. Male birds were kept for yielding of semen. The experiment commenced on 1st May and terminated on 30th June.

Five antistress agents were tested separately in broiler and broiler breeder hen. In both the cases group-1 was used as control and designated as T1. Diet for group-2 supplemented with ascorbic acid @ 0.8g $/ \mathrm{kg}$ of feed was designated as T2. The diet of the group which was designated as T3 was supplemented with sodium bi carbonate @ 15g/kg of feed. The fourth group which was designated as T4 were given Zeetress (M/S Indian Herbs, Saharanpur, U.P.) in drinking water @ 1g/ 100 birds per day. Stress roak ( M/S Dabur India Pvt. Ltd., New Delhi ) @ 10 ml / 100 birds per day were provided in drinking water to the 5 th group 
Effect of Antistress agents on Haemato-Biochemical profiles of broiler and breeder hen druing summer

Table-1: Mean and standard error of Haematological traits of Broilers at 6th week of age

\begin{tabular}{cccc}
\hline Treatment & Haemoglobing/d & R.B.C.Million $/ \mathbf{m l}$ & W.B.C.Thousand/ml \\
\hline T1 & $8.9 \mathrm{~b} \pm 0.049$ & $2.3358 \mathrm{ab} \pm 0.1426$ & $25.48 \mathrm{a} \pm 0.948$ \\
T2 & $8.317 \mathrm{c} \pm 0.028$ & $2.1075 \mathrm{~b} \pm 0.1234$ & $22.06 \mathrm{~b} \pm 0.602$ \\
T3 & $9.523 \mathrm{a} \pm 0.101$ & $2.8545 \mathrm{a} \pm 0.0807$ & $27.11 \mathrm{a} \pm 0.348$ \\
T4 & $8.930 \mathrm{~b} \pm 0.072$ & $2.1958 \mathrm{~b} \pm 0.1588$ & $24.88 \mathrm{ab} \pm 0.81$ \\
T5 & $8.7179 \mathrm{~b} \pm 0.119$ & $2.4535 \mathrm{ab} \pm 0.1160$ & $25.43 \mathrm{a} \pm 1.85$ \\
T6 & $8.9329 \mathrm{~b} \pm 0.229$ & $2.4414 \mathrm{ab} \pm 0.0963$ & $25.25 \mathrm{ab} \pm 1.14$ \\
\hline
\end{tabular}

which was designated as T5. Venlyte (M/S Venky Pharmaceutical of Venkateswar Group of Company, Pune)was given @ 10g in 4 lits of water to the birds belonging to the 6th group known as T6.

In case of broiler, haematological parameters such as Haemoglobin concentration in the blood, total erythrocyte count and total leucocyte count were performed at sixth week of age. Same parameters were studied in broiler breeder hen after the end of the experimental period. In case of broiler, biochemical parameters such as total blood glucose, total serum protein, total serum albumin, total serum cholesterol, total alkaline phosphatase(ALP) activity were performed at sixth week of age. In broiler breeder hen, total blood glucose and total serum protein were performed at the end of the experimental period. The meteorological data collected from the University Meteorological centre.

The data generated were subjected to statistical analysis according to Snedecor and Cochran (1967) for calculation of mean, standard error and making analysis of variance. When differences between the treatments were found to be significant statistically, DMR test (Duncun, 1955) as modified by Kramer (1956) was followed for separating the treatment means.

\section{Results and Discussion}

The maximum temperature during the month of May, varied from $36.4{ }^{\circ} \mathrm{C}$ to $44.7^{\circ} \mathrm{C}$ and the average maximum temperature was $39.5^{\circ} \mathrm{C}$. During the month of June, maximum temperature ranged from $28.0^{\circ} \mathrm{C}$ to $42.6^{\circ} \mathrm{C}$ with the average temperature of $36.9^{\circ} \mathrm{C}$. The average relative humidity was $67 \%$ for the month of May and $78 \%$ for the next month. Mean and standard error of haematological traits of broiler at 6th week of age in different treatment group are presented in table1.Haemoglobin concentration varied from $8.317 \mathrm{~g}$ to $9.53 \mathrm{~g}$ per dl of blood in different treatment groups. The control group $\mathrm{T} 1$ had a Haemoglobin content of $8.9 \mathrm{~g} / \mathrm{dl}$ of blood did not differ significantly from the groups fed with Zeetress (T4), Stressroak (T5) and Venlyte (T6). All these four groups had significantly more Haemoglobin than the group fed with vitamin C (T2).

The RBC count per $\mu 1$ of blood varied from 2.1075 to 2.8545 million in different treatment groups. The group receiving vitamin $C$ had lowest RBC count, although it did not differ significantly from the groups receiving Zeetress (T4), Stress roak (T5) and Venlyte (T6). The total WBC count was found to be significant between treatments. Sodium bi carbonate group (T3) had highest WBC count followed by T1, T5, and T6. The group which received vitamin -C (T2) had least number of WBC among the groups. Moye et al (1969) and Vo et al (1978) however found no variation in the RBC count due to temperature in case of males of poultry.

Mean and standard error for biochemical traits of broilers of 6th week of age in different treatment groups presented in table-2. Total blood glucose was measured in $\mathrm{mg} / 100 \mathrm{ml}$ of blood and was found to vary from $94.18 \mathrm{mg} / 100 \mathrm{ml}$ to $113.46 \mathrm{mg} / 100 \mathrm{ml}$ in different treatment groups. Differences between the treatment groups were found to be highly significant. $\mathrm{T} 2$ which had maximum glucose concentration did not differ from T4. Both these groups however differ

Table-2: Mean and standard error of biochemical traits of broilers at 6th week of age

\begin{tabular}{cccccc}
\hline Treatment & $\begin{array}{c}\text { Totalblood glucose } \\
\text { (mg/100ml of blood) }\end{array}$ & $\begin{array}{l}\text { Total serum protein } \\
(\mathbf{g} / \mathbf{1 0 0} \mathbf{m l} \text { of serum) }\end{array}$ & $\begin{array}{l}\text { Total serum albumin } \\
\text { (g/100ml of serum) }\end{array}$ & $\begin{array}{l}\text { Total alkaline phosphatase } \\
\text { activity(m/U/mi/min) }\end{array}$ & $\begin{array}{l}\text { Serum cholesterol } \\
\text { (mg/dl of serum) }\end{array}$ \\
\hline T1 & $103.74 \mathrm{~b} \pm 2.1913$ & $2.162 \mathrm{~d} \pm 0.084$ & $0.545 \mathrm{c} \pm 0.006$ & $33.209 \mathrm{ab} \pm 0.1795$ & $82.54 \mathrm{~d} \pm 1.03$ \\
T2 & $113.46 \mathrm{a} \pm 0.828$ & $3.682 \mathrm{~b} \pm 0.111$ & $0.944 \mathrm{~b} \pm 0.041$ & $33.341 \mathrm{ab} \pm 1.1283$ & $89.08 \mathrm{c} \pm 0.299$ \\
T3 & $100.77 \mathrm{bc} \pm 1.0035$ & $2.513 \mathrm{c} \pm 0.089$ & $0.563 \mathrm{c} \pm 0.0021$ & $31.43 \mathrm{c} \pm 0.3537$ & $100.51 \mathrm{~b} \pm 2.033$ \\
T4 & $112.8 \mathrm{a} \pm 3.394$ & $4.47 \mathrm{a} \pm 0.009$ & $1.25 \mathrm{a} \pm 0.016$ & $33.30 \mathrm{ab} \pm 0.539$ & $109.81 \mathrm{a} \pm 1.269$ \\
T5 & $94.178 \mathrm{~d} \pm 2.892$ & $2.601 \mathrm{c} \pm 0.089$ & $0.846 \mathrm{~b} \pm 0.073$ & $31.49 \mathrm{bc} \pm 0.383$ & $65.641 \mathrm{f} \pm 1.46$ \\
T6 & $96.4016 \mathrm{~cd} \pm 2.1455$ & $4.5469 \mathrm{a} \pm 0.091$ & $1.282 \mathrm{a} \pm 0.081$ & $33.53 \mathrm{a} \pm 0.053$ & $74.0007 \mathrm{e} \pm 1.42$ \\
\hline
\end{tabular}


Effect of Antistress agents on Haemato-Biochemical profiles of broiler and breeder hen druing summer

Table-3. Mean and standard error for Haematological parameter of Broiler Breeder Hens

\begin{tabular}{cccc}
\hline Treatment & Haemoglobin $\mathbf{g} / \mathbf{d l}$ & Leucocytes $/ \mathbf{m l}$ & $\mathbf{R . B . C . M i l l i o n} \mathbf{~} \mathbf{m l}$ \\
\hline T1 & $9.00 \mathrm{c} \pm 0.208$ & $27720 \mathrm{a} \pm 892.33$ & $2.86 \mathrm{a} \pm 0.071$ \\
T2 & $9.33 \mathrm{abc} \pm 0.406$ & $27373 \mathrm{a} \pm 606.45$ & $2.703 \mathrm{a} \pm 0.108$ \\
T3 & $10.13 \mathrm{a} \pm 0.321$ & $27726.66 \mathrm{a} \pm 307.17$ & $2.9867 \mathrm{a} \pm 0.013$ \\
T4 & $9.30 \mathrm{bc} \pm 0.088$ & $28263.33 \mathrm{a} \pm 696.39$ & $2.88 \mathrm{a} \pm 0.069$ \\
T5 & $9.733 \mathrm{abc} \pm 0.12$ & $29266.66 \mathrm{a} \pm 88.34$ & $2.74 \mathrm{a} \pm 0.144$ \\
T6 & $9.833 \mathrm{ab} \pm 0.41$ & $28486.66 \mathrm{a} \pm 638.44$ & $2.80 \mathrm{a} \pm 0.0203$ \\
\hline
\end{tabular}

significantly from rest of the groups for blood glucose. DMR test also revealed no significant difference between $\mathrm{T} 1$ and T3, T3 and T6, and T5 and T6.

Total serum protein was estimated in $\mathrm{g} / 100 \mathrm{ml}$ of serum and varied from $2.162 \mathrm{~g}$ to $4.5 \mathrm{~g}$ in different treatment groups. T6 which had the highest serum protein concentration did not differ from $\mathrm{T} 4$ whereas both these groups were found to be significantly different from rest of the groups. Total serum albumin concentration was highest for T6 followed by T4, T2, $\mathrm{T} 5, \mathrm{~T} 3$ and $\mathrm{T} 1$ in that order. DMR test revealed no significant difference between T6 and T4, T5 and T2, and $\mathrm{T} 3$ and $\mathrm{T} 1$.

Total alkaline phosphatase activity was measured $\mathrm{ml} \mathrm{U} / \mathrm{ml} / \mathrm{min}$ of serum. DMR test revealed no significant differences among Venlyte, Zeetress, vitamin -C and control groups. Sodium bi carbonate group had least alkaline phosphatase activity of 31.43 $\mathrm{ml} \mathrm{U} / \mathrm{ml} / \mathrm{min}$ of serum.

Total serum cholesterol was measured in $\mathrm{mg} / \mathrm{dl}$ of serum. It varied from 65.54 to $109.81 \mathrm{mg} / \mathrm{dl}$ of serum in different treatment groups. T5 had least serum cholesterol and significantly differ from rest of the groups. T4 had significantly higher serum cholesterol. Deaton et al (1969) found higher plasma protein in birds in higher temperature but Vo et al (1978) found decline in plasma protein in high temperature. Mean and standard error of haematological traits measured in broiler breeder hen are presented in table-3.Amount of Haemoglobin for different treatment groups ranged from 9.00 to 10.13 g/dl. T3 had highest Haemoglobin concentration followed by T6, T5, T2, T4 and T1 in this order. DMR test revealed no significant difference among the groups receiving vitamin-C (T2), Sodium bi carbonate (T3), Stressroak (T5) and Venlyte (T6). The total RBC count varied from 2.70 to 2.98 million per $\mu 1$ of blood in different groups with statistically no significant differences amongst the groups. The leucocyte count of blood ranged from 27,373 to 29,266 per ml of blood in different treatment groups. Differences between treatment groups were not significant statistically.

Mean and standard error of biochemical traits measured in broiler breeder hen is presented in table- 4 . The total blood glucose level ranged from 171.75 to $186.49 \mathrm{mg} / 100 \mathrm{ml}$ of blood. T1 which had least total blood glucose level did not differ significantly from T2, T4 and T5. Differences between T2, T3, T4, T5 and T6 were not found to be significant. Total serum protein concentration ranged from 5.46 to $6.22 \mathrm{~g} / 100$ $\mathrm{ml}$ of serum in different treatment groups. Analysis of variance revealed no significant difference between the treatments.

\section{Acknowledgement}

Authors are thankful to WPSA(IB) for awarding Dr. B. V. Rao (WPSA-IB) Research Grants for conducting the study.

\section{References}

1. Deaton, J.W., et.al. (1969). Hematocrit, hemoglobin and plasma-protein levels of broilers reared under constan temperatures. Poult. Sci. 48 (4): 1993-1996.

2. Duncan, D.B. (1955). Multiple range and multiple F-tests. Biometrics. 11: 1-42.

3. Kramer, C.Y. (1956) Estimation of multiple range tests to group means with unequal number of replications.

Table-4. Mean and standard error for Biochemical profile of Broiler Breeder Hens

\begin{tabular}{ccc}
\hline Treatment & Total blood glucose $\mathbf{( m g / 1 0 0 m l ~ o f ~ b l o o d ) ~}$ & Total serum protein $(\mathbf{g} / \mathbf{1 0 0} \mathbf{m l ~ o f ~ s e r u m ) ~}$ \\
\hline T1 & $171.75 b \pm 5.204$ & $6.15 \mathrm{a} \pm 0.2466$ \\
T2 & $177.9 \mathrm{ab} \pm 1.694$ & $5.61 \mathrm{a} \pm 0.3837$ \\
T3 & $183.49 \mathrm{a} \pm 1.79$ & $5.89 \mathrm{a} \pm 0.254$ \\
T4 & $178.7 \mathrm{ab} \pm 0.65$ & $6.226 \mathrm{a} \pm 0.1659$ \\
T5 & $180.49 \mathrm{ab} \pm 3.392$ & $5.466 \mathrm{a} \pm 0.2008$ \\
T6 & $186.49 \mathrm{a} \pm 3.067$ & $5.8267 \mathrm{a} \pm 0.1947$ \\
\hline
\end{tabular}


Effect of Antistress agents on Haemato-Biochemical profiles of broiler and breeder hen druing summer

Biometry. 12:307-310.

4. Moye, R.J., Jr., Washburn, K.W. and Huston, T.M. (1969).

Effects of environmental temperature on erythrocyte numbers and size. Poult. Sci. 48(4): 1683-1686.

5. Snedecor, G.W. and Cochran, W.G. (1967) Statistical methods. The Iowa State University Press, Ames, U.S.A.

6.

Vo, K.V., Boone, M.A. and Johnston, W.E. (1978). Effect of

three lifetime ambient temperatures on growth, feed and water consumption and various blood components in male and female Leghorn chickens. Poult. Sci. 57: 798-803. 